DIGITAL COMMONS
@ UNIVERSITY OF SOUTH FLORIDA

Volume 2

Issue 2 Volume 2.2 (Fall 2012): Open Access
ABO: Interactive Journal for

Women in the Arts, 1640-1830

2012

\title{
Teaching British Women Playwrights of the Restoration and Eighteenth Century, edited by Bonnie Nelson and Catherine Burroughs
}

Judy A. Hayden

University of Tampa, jhayden@ut.edu

Follow this and additional works at: https://digitalcommons.usf.edu/abo

Part of the Dramatic Literature, Criticism and Theory Commons, Educational Methods Commons, Feminist, Gender, and Sexuality Studies Commons, and the Literature in English, British Isles Commons

\section{Recommended Citation}

Hayden, Judy A. (2012) "Teaching British Women Playwrights of the Restoration and Eighteenth Century, edited by Bonnie Nelson and Catherine Burroughs," ABO: Interactive Journal for Women in the Arts, 1640-1830: Vol.2: Iss.2, Article 12. http://dx.doi.org/10.5038/2157-7129.2.2.12

Available at: https://digitalcommons.usf.edu/abo/vol2/iss2/12

This Reviews is brought to you for free and open access by Digital Commons @ University of South Florida. It has been accepted for inclusion in ABO: Interactive Journal for Women in the Arts, 1640-1830 by an authorized administrator of Digital Commons @ University of South Florida. For more information, please contact digitalcommons@usf.edu. 


\section{Teaching British Women Playwrights of the Restoration and Eighteenth Century, edited by Bonnie Nelson and Catherine Burroughs}

\section{Keywords}

eighteenth-century drama, eighteenth-century theater, female playwrights, pedagogy, theater and culture, women's writing

\section{Creative Commons License}

(c) $($ ) $\ominus$

This work is licensed under a Creative Commons Attribution-No Derivative Works 3.0 License. 
Bonnie Nelson and Catherine Burroughs, eds. Teaching British Women Playwrights of the Restoration and Eighteenth-Century.New York: The Modern Language Association, 2010. \$25.00. ISBN 978-1-60329-083-8.

Reviewed by Judy A. Hayden

University of Tampa

Assembling a text such as Teaching British Women Playwrights of the Restoration and Eighteenth-Century is never an easy task. In this regard, the editors, Bonnie Nelson and Catherine Burroughs, deserve kudos for their efforts. In drawing on scholars from a number of different countries and disciplines, Nelson and Burroughs offer a multiplicity of views and ideas on pedagogical aspects of female playwrights in this historical period.

The collection opens with "Part I: Historical Contexts." Although the authors of these essays do explore to some extent the historical and social contexts in which these female playwrights wrote, the main focus is largely on gender and gender issues. In her essay, "Working in the Theater: Women Playwrights, 1660-1750," Jane Milling cautions against searching for "female solidarity underpinned by a latent feminism" (15). Milling points out that female playwrights took active roles in the production of their plays, and whether directing rehearsals or negotiating with managers, they were alert to the demands of stagecraft as well as audience expectations. George E. Haggerty notes the changes that took place in the theater after the Restoration with the entrance of the actresses and female playwrights. In "Regendering the Restoration Stage: Women and Theater, 1660-1720," he argues that while there were no major differences between male- and female-authored plays, women writers could offer subtle variations that placed greater emphasis on female roles and issues. In "Women Spectators, Playwrights, and Performers and the Restoration Stage," Jacqueline Pearson explores women's roles in the theater as consumers and active participants-both as actresses and as playwrights. Catherine Burroughs in "Women and Playwriting, 1750-1800" surveys the later eighteenth century and notes the difficulties playwrights encountered in writing for the patent stage after the Stage Licensing Act of 1737. The rise of the illegitimate theater, the provincial theater, and closet drama offered new opportunities for both women and men. Although the first three essays in Part I seem to overlap a great deal in content, each nevertheless has something distinctive to offer as well.

While Burroughs and Nelson note in their introduction that the heart of Teaching British Women Playwrights is "Part II: Individual Playwrights," and while ten female playwrights are examined, there is little insight as to the editors' purpose or objective in this section. The essays are rather wide-ranging, covering a diverse selection of female playwrights, from Aphra Behn to Joanna Baillie, and topics from politics and philosophy to gender identity and theater criticism. Although several of the essays note some historical difficulties faced by Restoration and eighteenth-century female playwrights, this section is not specifically a historical or contextual study of the playwrights themselves, nor does the purpose of the essays appear to lie on any 
specific trajectory. The focus of these essays is as individual as the playwrights and scholars themselves. For example, Nancy Copeland's essay on Aphra Behn is less about Behn per se than about the producible qualities and recent productions of Behn's plays, while Roxanne KentDrury explores Catharine Trotter's appeal to audience taste and theater management. Betsy Bolton's essay offers a pointed explication of gender identity in one of Hannah Cowley's plays, A Bold Stroke for a Husband, whereas Misty Anderson's essay explains her teaching methodology for several of Susanna Centlivre's plays. Although there is certainly value in the dissimilarity of approaches and content here, one comes away with a sense of fracture in this section.

What is perhaps more troublesome in Part II is the lack of essays on early playwrights such as Margaret Cavendish, Katharine Philips, Frances Boothby, Elizabeth Polwhele, and Delarivier Manley, as well early anonymous playwrights, such as "Ariadne," although there is brief mention and occasional discussion of some of these women in other parts of this text. The "Individual Playwrights" section is much more heavily weighted on late eighteenth-century women playwrights, even though early playwrights, such as Philips and Behn, forged the path, as Virginia Woolf noted, for later women writers.

While Part II's content and structure is problematic in many ways, my concern as I approached the five essays in "Part III: The Playwright as Novelist," was quickly dispelled by two outstanding articles in this section. In her essay "Frances Brooke's The Excursion and Eighteenth-Century Women's Theater," Michelle Ruggaber Dougherty suggests that teachers of women playwrights might begin with Brooke's novel, given that its female protagonist as wouldbe playwright provides a depiction of the difficulties faced by women who desired to write for the public stage; hence, Brooke's novel supplies much-needed student historical context, such as social history (i.e., female propriety) through the debate about public and private spheres. In “"The Stage Not Answering My Expectations': The Case of Eliza Haywood," Catherine Ingrassia argues that "literary history's tendency to flatten the fluid relationship among genres" fails to capture an accurate picture of "reading and writing experiences in the early eighteenthcentury" (213). Pointing out Haywood's use of dramatic texts as cultural reference points in her fiction and noting the strengths Haywood's experience as playwright provides for her fiction, Ingrassia argues the importance of exploring the "mutually informing" relationship between drama and fiction. The other essays in this section, Francesca Saggini's "Teaching Evelina as a Dramatic Text," Gillian Skinner's "Class, Gender, and Inheritance in Burney's A Busy Day and The Woman Hater," and Anna Lott's "Elizabeth Inchbald's Revolutionary Writings," fill out the remainder of Part III and demonstrate well the potential benefit to students studying women playwrights through a multiplicity of genres.

Although Nelson and Burroughs observe in their introduction an essential recognition that "teaching plays by female playwrights alongside their more frequently studied male counterparts and other women dramatists can result in significant insights," and although they set aside "Part IV: Comparative Approaches" specifically for this purpose, there is, in fact, very little work here 
with comparative approaches between male and female dramatists. There are only four essays in this section, a number which unfortunately does not reflect the importance of such an assessment, and only one essay actually fulfills that male/female comparative objective. Emily Hodgson Anderson's "She Stoops to Strategem: A Comparative Approach to Eighteenth-Century Comedy," compares and contrasts Oliver Goldsmith's comedy She Stoops to Conquer (1773) with Hannah Cowley's The Belle's Strategem (1780) to challenge assumptions about gender difference. Although Pilar Cuder-Dominguez's "Gender, Race, and Party Politics in the Tragedies of Behn, Pix, and Manely" does make mention of Behn's source play for Abdelazar; or, the Moor's Revenge (1677), Lust's Dominion; or, The Lascivious Queen-ascribed variously to Thomas Dekker, William Haughton, and/or John Day-her comparative work is principally between the three women playwrights in the title of her essay and their use of Eastern settings to probe the shift from "male-centered heroic plays to women-centered pathos" (267). The other two essays in this section, those by Tassie Gwilliam and Kathleen Leicht, also work with Cowley's The Belle's Strategem and other female writers, either to investigate desire and disguise or to point out the shift in social ideas about women and marriage that occurred in the historical period between these two plays.

The largest section, as one would expect in such a volume, is "Part V: Classroom Strategies," which offers "theoretical and practical considerations" to teaching women playwrights at both the undergraduate and graduate level. While all of these essays provide excellent examples and strategies for working with female-authored plays, it is disappointing that half the twelve essays in this section focus on Behn or Centlivre, with little offered on other women's plays. To counter this, perhaps a thematic or contextual approach here would have offered a more inclusive scope for discussion of these early women playwrights rather than division by individual plays. In fact, three of the essays in this section do precisely that. In "Using Production to Teach Women Playwrights," Marie E. McAllister discusses the benefits of a performative approach to classroom teaching of drama. Thomas $\mathrm{C}$. Crochunis explores ways of teaching drama that incorporates women's writing and traumatic experiences in his essay, "Pre- and Postrealist Dramaturgy: Women Writers, Silence, Speech, and Trauma." And Jean I. Marsden concludes this section and the volume with her "Imagining a Course: Teaching Women Dramatists," in which she challenges herself to create a course on Restoration and eighteenth-century women dramatists, placing these writers in their theatrical, literary, and social contexts, while connecting the required readings with these women's lived experiences.

In Part V, Laura Rosenthal and Anita Pacheco both work with Behn's The Rover. In "Cultural Studies in the Classroom: Behn's The Rover," Rosenthal notes that in most departments, where typically the organization is by genre and period, teaching a course via cultural studies can be difficult. She argues for a comparative approach in teaching The Rover, and typically asks her students to interrogate this play after they have read works by Dryden, Wycherley, and Etherege. Pacheco suggests a different approach in her essay "Teaching Behn's The Rover," where her central goal is to help students grasp Behn's unrivalled stagecraft, while also acquainting 
students with the main properties of the Restoration theater. Cynthia Richards, on the other hand, finds Behn's The Widow Ranter a Restoration play with which her students can identify owing to its "home" setting. In "To Whom Does the New World Belong? Teaching Behn's The Widow Ranter," Richards asks her students to ponder the extraordinarily complex question of "possession" and national identity.

The three essays on Centlivre begin with Ellen MacKay's "Performance Theory: Attending to the Monkey Wrench in Centlivre's The Busie Body." While MacKay's essay does not offer classroom pedagogy directly, she does point out that through Miranda's stutter and the "monkey scene," Centlivre invites a reassessment of the dramatic conventions of comedy. Melinda C. Finberg seeks ways to make Centlivre's works come alive to her students, so that they are not simply "words on a page," but rather "living theater." In her essay, "Centlivre and the Stage Sodomite," Finberg notes the importance not only of teaching students about the social context of The Busybody (1709), but also of the significance of facilitating their visualization of the physical stage and their understanding the playwright's coded sexual language. In "On Using Thelma and Louise to Teach Centlivre's The Wonder,' Jones DeRitter conveys a refreshing, comparative note to the teaching of Centlivre's play, The Wonder: A Woman Keeps a Secret (1714). De Ritter brings entry-level students to an appreciation of the eighteenth-century stage through a comparison of similar art forms, where students can explore issues such as situations, characters, friendships, and personal growth. The other three essays in this section, by Vimala Pasupathi, Marjean D. Purinton, and Daniel O'Quinn, provide classroom strategies for teaching Cavendish, Burney, and Inchbald respectively.

While the individual essays in this collection are well-written, the structure of Teaching British Women Playwrights seems unbalanced. The text lacks a well-designed structure, the sections are uneven, nor do all of the sections (or essays) fulfill the objectives noted in the introduction (or section heading). One reads through this text with a sense of a conference paper collection. Still, providing this much information in one text is a difficult task, and the editors should be given credit for their effort. Furthermore, whatever my concerns with this text, my comments are in no way meant to conclude that the essays in Teaching British Women Playwrights of the Restoration and Eighteenth Century are necessarily problematic. In fact, all the essays in this collection are informative and certainly offer a number of viewpoints and options for teaching any of these women playwrights.

Still, some of these essays are particularly outstanding and deserve individual recognition. Catherine Burroughs' essay on closet drama and the illegitimate theater is fascinating and made me rethink a topic I typically tend to forget as my own research lies largely in the early part of the long eighteenth century. Misty G. Anderson's detailed explanation of her teaching methodology on Susanna Centlivre and Nora Nachumi's beautifully written-if not electricessay on Elizabeth Inchbald as theatre critic are, frankly, amazing. Emily Hodgson Anderson's essay, which explores comparative contexts as a means to challenge assumptions about gender difference, is also particularly noteworthy, as are the pedagogical moments she points out along 
the way. Finally, two other essays deserve particular recognition: Marie E. MacAllister's lucid essay on performative learning furnishes outstanding ideas for pedagogical opportunities through "dramatic readings," and Jean I. Marsden's well-written challenge to create a course on women dramatists in their theatrical, literary, and social contexts ends with an ambitious syllabus that can be honed, redeveloped, or expanded depending on the students' level.

No text is without its problems and this is certainly true with collections such as this. Even so, Teaching British Women Playwrights of the Restoration and Eighteenth Century is certainly a worthwhile compilation and I would point out that this text would be an asset to any library, any department library, or any individual teaching British women playwrights in the long eighteenthcentury. 